\title{
Hommage à José Garanger
}

\section{Claude Robineau}

\section{(2) OpenEdition}

Journals

Édition électronique

URL : http://journals.openedition.org/jso/1113

DOI : 10.4000/jso.1113

ISSN : 1760-7256

Éditeur

Société des océanistes

Édition imprimée

Date de publication : 1 juin 2007

Pagination : 164

ISBN : 978-2-85430-010-9

ISSN : 0300-953x

Référence électronique

Claude Robineau, «Hommage à José Garanger », Journal de la Société des Océanistes [En ligne], 124 | Année 2007-1, mis en ligne le 08 avril 2008, consulté le 15 septembre 2020. URL : http:// journals.openedition.org/jso/1113

(C) Tous droits réservés 


\section{Hommage à José Garanger}

par

\section{Claude ROBINEAU}

C'est entre les fêtes de Noël et celles du jour de l'an que José Garanger nous a quittés. C'est un message de Maurice Hardy, son cousin, qui a appris aux membres de notre Société le décès de notre ancien président survenu le mardi 26 décembre 2006 à Noisy-le-Grand. En cette période de l'année, de nombreux collègues étaient absents. Christian Coiffier, secrétaire général, a représenté la société des Océanistes aux obsèques qui se sont déroulées dans l'intimité. Notre société a fait également publier une annonce de décès dans le journal Le Monde.
Le professeur José Garanger assura la succession de Patrick O'Reilly comme secrétaire général de notre société. Il assuma ces responsabilités durant dix années (1972-1982) avant de devenir président de 1983 à 1986, puis vice-président jusqu'en 2004.

Archéologue spécialiste du monde océanien, il sût faire partager à plusieurs générations d'étudiants et de chercheurs sa passion de l'Océanie et son respect pour les peuples du Pacifique. Nous consacrerons dans un prochain numéro plusieurs pages à la mémoire de ce grand savant. 